\title{
二軸延伸フィルムの延伸に伴う分子配向挙動
}

\author{
第 2 報 二軸延伸ポリエチレンテレフタラート \\ フィルムの結晶各回折面の配向挙動
}

\author{
丹羽貴裕 $* 1$ 図師泰伸 ${ }^{* 2} \cdot$ 日比貞雄 $* 2$ \\ 永田紳一 $* 3$ ・谷 知*2
}

\section{Molecular Orientation Behavior with Drawing of Biaxially Stretched Film}

\section{Part II Orientation Behavior of Crystal Each Diffracted Plane of Biaxially Stretched Poly (ethylene terephthalate) Film}

\author{
Takahiro Niwa*1, Yasunobu Zushi*2, Sadao HiBI*2 \\ Shinichi NAGATA*3, Satoru TANI ${ }^{* 2}$
}

\begin{abstract}
Biaxially stretched poly (ethylene terephthalate)(PET) films have been characterized by wide angle $\mathrm{X}$-ray diffraction. Pole figures were developed for wide angle diffraction peaks. These are used to interpret structural changes in the films associated with various degrees of biaxial stretching and subsequent constrained annealing. We investigated typical pole figures for (100) and (105) planes normal of biaxially stretched and annealed films. In the triclinic unit cell of PET crystal the phenyl ring planes are roughly parallel to $(100)$ planes and $(\overline{105})$ planes are roughly perpendicular to the chain axis.
\end{abstract}

Key words : Biaxial stretching/Poly (ethylene terephthalate)/X-ray diffraction/ Pole figure/Preferential orientation

*1 大同メタル工業(株) 技術研究所 犬山市前原（干 484）

Daido Metal Co.

Maehara, Inuyama, Aichi 484 Japan

*2 名古屋工業大学 工学部 材料工学科 名古屋市昭和区御器所町 (广 466)

Department of Materials Science for Engineering, Nagoya Institute of Technology

Gokiso-cho, Showa-ku, Nagoya 466 Japan

*3 新王子製紙(株) 計測機器開発部

尼崎市常光寺 (空 660)

Shinoji Paper Co.

Jokoji, Amagasaki, Hyogo 660 Japan 1995. 5.11 受理

\section{1. 緒言}

前報1では，直交二軸延伸ポリエチレンテレフタラ 一ト（以後 OB-PET と略記する）フィルムの延伸に 伴う分子配向挙動の評価の中で, 延伸に伴う結晶化, 非晶鎖内で発生するコンフォメーション変化 ${ }^{2)}$, 複屈 折および誘電率の異方性などを調査した結果について 報告した。

本報告では，同じ OB-PET フィルムの結晶回折面 の配向挙動を極点図形により調査した結果について報 告する.これまで, OB-PET フィルムの極点図形を用

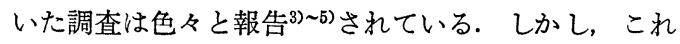


らはいずれも延伸に伴う塑性変形時の分子配向挙動を 言及していない，著者らは，この塑性変形時の分子配 向機構の多結晶集合体モデル67,7) による評価法を用い て, OB-PET 微結晶の配向分布関数の評価を目的と して打り，次報で報告を予定している.

著者らのグループでは，無極性材料であるポリエチ レン88,9)拈よびポリピロピレン ${ }^{10) ~ 12) ~ フ ィ ル ム の ロ ー ル ~}$ 圧延に伴う結晶各回折面の配向分布関数の調查, 解析 を行った. いっぽう，極性材料としてロール压延 PET フィルム拉よび同じフィルムを Off-axis Angle 方向へ再延伸する際の延伸に伴う結晶各回折面の配向 挙動を極点図形により調查した ${ }^{133,14)}$. この結果, 無極 性ポリエチレンの結晶は, 変形時に付与されるせん断 応力により分子鎖軸まわりで, 結晶粒子が塑性滑りし やすい結晶であるのに対し, PET の結晶は, 分子鎖 内に存在するベンゼン環にほぼ平行な (100) 面が，口 一ル圧延によりフィルム面に平行に配向し，せん断応 力が付与されても, 分子鎖軸まわりで塑性滑りが起こ
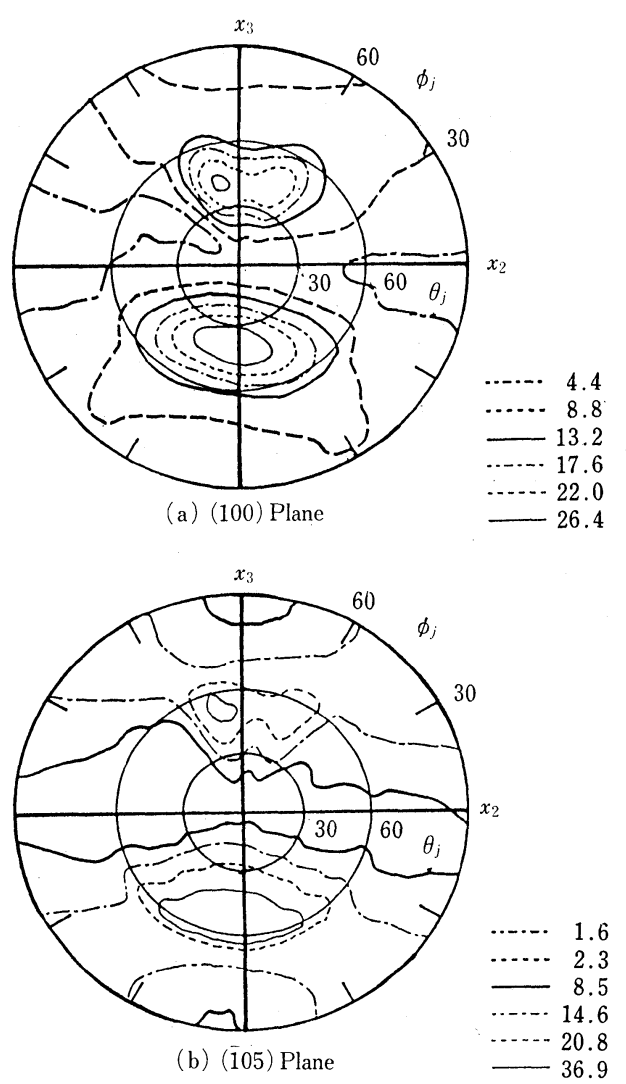

Fig. 1 Wide angle $\mathrm{X}$-ray pole figures of films stretched strip-biaxially at $90^{\circ} \mathrm{C}$ and fixed annealed at $200^{\circ} \mathrm{C}$, stretch ratio is $1.5 \times 1.0$
りにくい結晶であることが明らかになった．このよう に材料のもつ特徵を解析する目的で，本報では OBPET フィルムの延伸に伴う結晶各回折面の配向分布 関数を調查し, 次報でこの変形機構を解析する.

\section{2. 実験}

2.1 試料 前報》に報告した試料を使用した。

\section{2 フィルムの直交二軸延伸および熱処理}

前報 ${ }^{1} の$ 延伸フィルムを測定用試料としたが，極点 図形の解析には，回折強度が充分でないので，結晶化 度を $55 \%$ 以上に向上させるべく，各二軸延伸フィル ムをゴンノ水圧機製作所製の熱プレスを使用した．温 度 $200^{\circ} \mathrm{C} \pm 1^{\circ} \mathrm{C}$, 圧力 $50 \mathrm{MPa}$ の条件の下で, 2 時間 熱処理し，その後，放冷してX線回折強度測定用 ${ }^{13}$ の 試料とした。な括，熱処理試料は，結晶化度約 $60 \%$ であることを密度勾配管の測定で確認した。
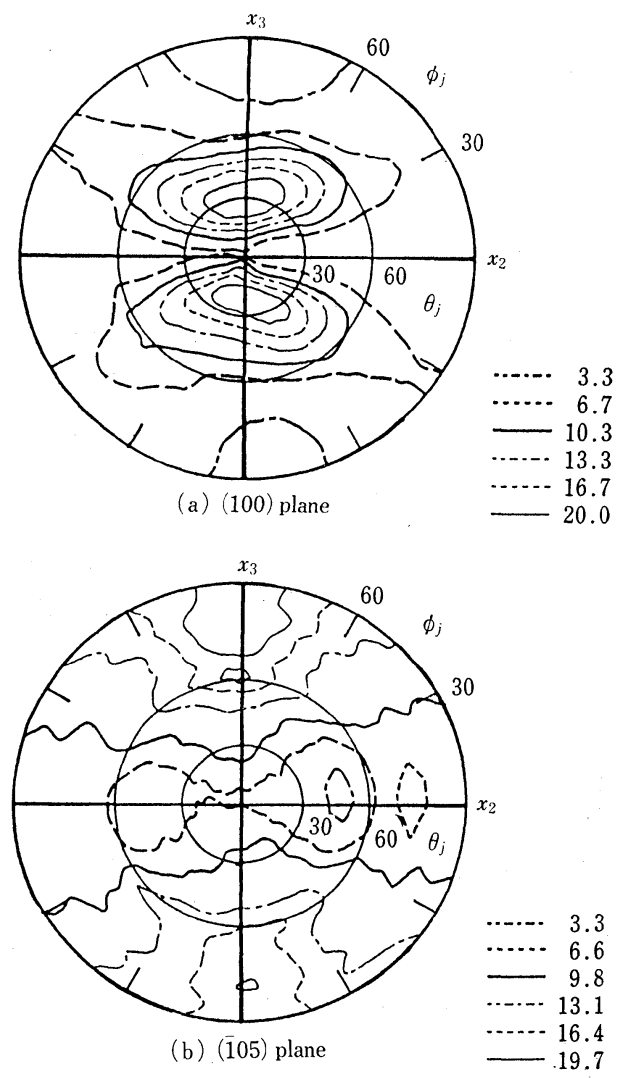

Fig. 2 Wide angle $X$-ray pole figures of films stretched strip-biaxially at $90^{\circ} \mathrm{C}$ and fixed annealed at $200^{\circ} \mathrm{C}$, stretch ratio is $2.5 \times 1.0$ 


\section{3 極点図形の測定}

$\mathrm{X}$ 線回折強度 の 測定装置は, 理学電機製, RINT 1000 に極点試料台 (MJ 200 HY 3) を付設して行った. 測定にあたり，反射法 ${ }^{15)}$ および透過法 ${ }^{16)}$ の測定を併用 し，非晶性散乱，空気散乱拈よび吸収，照射面積の補 正は，すでに報告している方法 ${ }^{8)}$ に準じて行い，得ら れた各回折面の 反射，透過の唛称合わせも，これま で8) と同じ方法で行った。 な拐：今回使用した測定系 は，全自動測定により極点図形の作図が行われるので, 各回折強度分布の重なりが存在することから，比較的 単独に近い回折寄与とみられる(100)，(105) 面の回 折強度分布のみを測定した。

\section{3. 実験結果および考察}

\section{1 極点図形による回折面の配向分布関数}

Figs. 1 4 は, 一軸拘束一軸延伸フィルム（前報 ${ }^{1)}$ の試料Aに属する) の主延伸倍率 $\lambda_{3}=1.5,2.5,3.0$, 3.5 倍各延伸フィルムの (100) 面拈よび (105) 面法
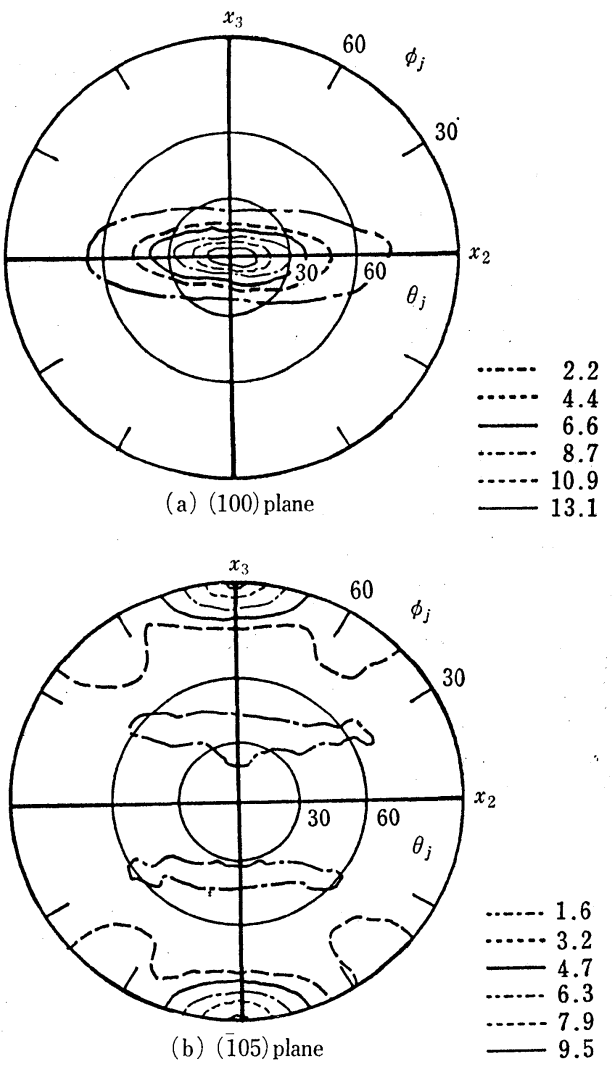

Fig. 3 Wide angle $\mathrm{X}$-ray pole figures of films stretched strip-biaxially at $90^{\circ} \mathrm{C}$ and fixed annealed at $200^{\circ} \mathrm{C}$, stretch ratio is $3.0 \times 1.0$
線の極点図形を示した. 各図とも，延伸フィルムの厚 さ方向 $\left(x_{1}\right.$ 軸) を極として, 幅方向 $\left(x_{2}\right.$ 軸, TD), 主 延伸方向 ( $x_{3}$ 軸, MD) を極図の面内で図示した. い ずれの図とも，(a) は PET 結晶内のベンゼン環を含 む (100) 面の法線の配向分布の様子を示している. 低 延伸倍率である $1.5,2.5$ 倍試料では, フィルムの厚 さ方向より極角 $\theta_{j}$ が $30^{\circ} \sim 45^{\circ}$ ずれ，方位角 $\phi_{j}$ は $90^{\circ}$ の厚さ方向から MD 方向一傾いた位置に, 最む 強い強度域をもつ分布を示す*．この面の分布は， 3.5 倍と延伸倍率が高くなると, 最も強い回折強度領域が フィルムの厚さ方向である極方向に集中している.こ のような挙動は，ポリエチレン結晶の (200) 面法線の 配向挙動9)と非常に似かよった挙動になっている。

いっぽう，(b) 図は PET の分子鎖軸方向と極角 $\Theta_{j^{13}}$ で約 $10^{\circ}$ 傾いた方向である(105) 面の法線の

* 極角 $\theta_{j}$ は, フィルムの厚さ方向 $x_{1}$ 軸を極として $x_{2}-x_{3}$ 面方向へのベクトルの傾きを表す角であり, 方位角 $\phi_{j}$ は $x_{1}-x_{2}$ 軸より反時計まわりの回転を表す角度である.
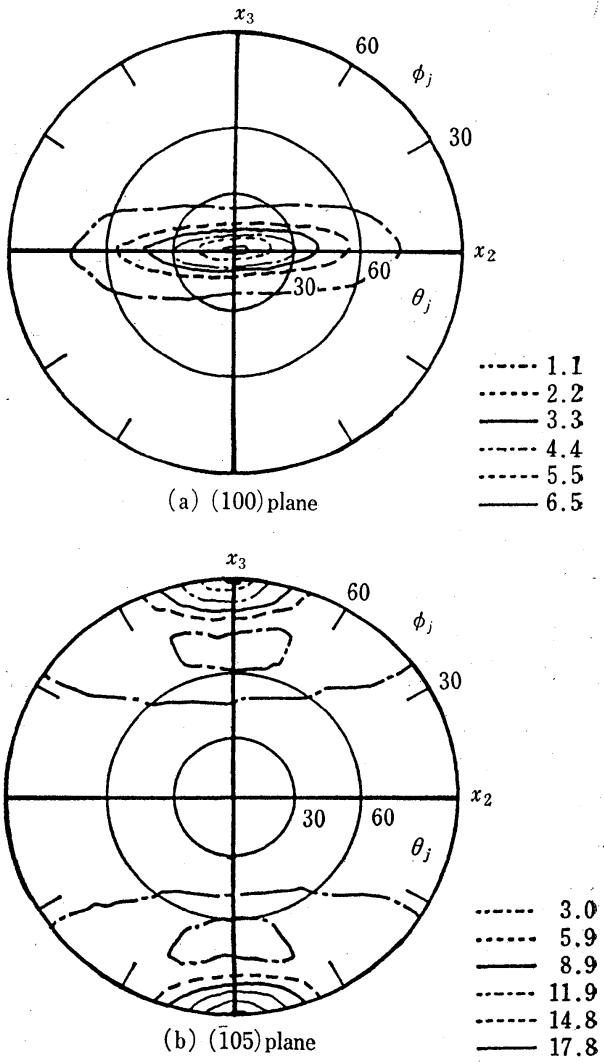

Fig. 4 Wide angle $\mathrm{X}$-ray pole figures of films stretched strip-biaxially at $90^{\circ} \mathrm{C}$ and fixed annealed at $200^{\circ} \mathrm{C}$, stretch ratio is $3.0 \times 1.0$ 

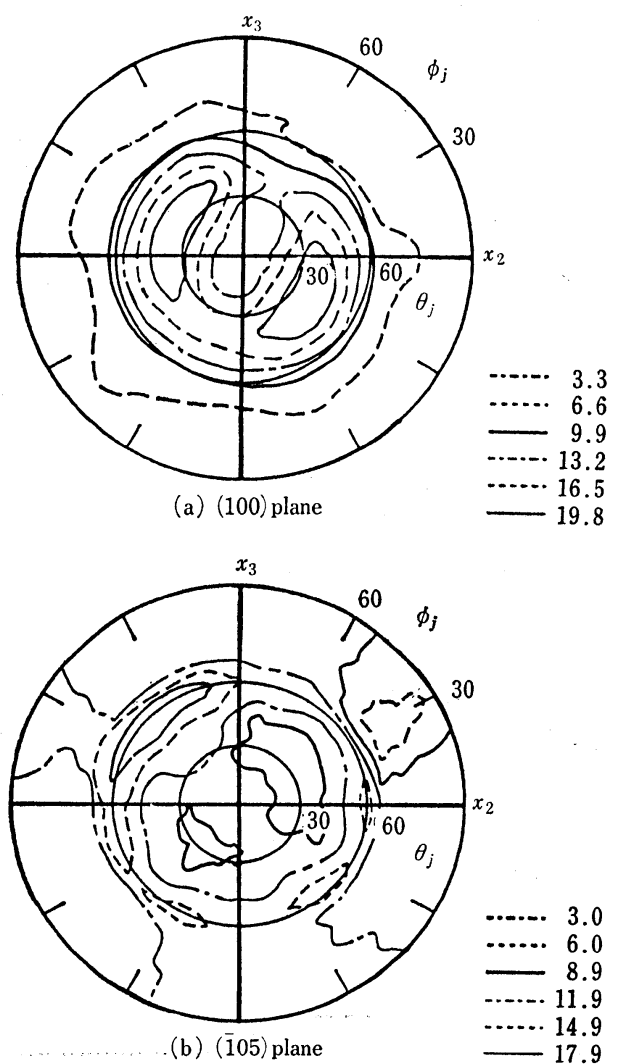

Fig. 5 X-ray pole figures of films stretched simultaneous biaxially at $90^{\circ} \mathrm{C}$ and fixed annealed at $200^{\circ} \mathrm{C}$, stretch ratio is 1.5 $\times 1.5$

極点図形を，（a）図と同じ表示法の 極点図形で示し た. 延伸初期 (100) 面の法線が,フィルムの厚さ方向 より, $30^{\circ} \sim 45^{\circ}$ ほど傾いて強度の極大を示す配向状 態に対応し，両面法線ベクトルの方のずれが，結晶 単位胞内で約 $80^{\circ}$ であり,この結果, 極点図形上では, フィルムの厚さ方向上り極角 $\theta_{j}=60^{\circ}$, 方位角 $\phi_{j}=$ $90^{\circ}$ の $x_{1}-x_{3}$ 軸上に極大をるつ分布を示している. 延 伸倍率の増加にしたがって， $x_{3}$ 軸に近い位置に分布の 極大が集中する.

この結果は，一軸拘束一軸延伸の主延伸効果が次第 飞強く作用し，結晶分子鎖軸である $c$ 軸の方向に近い (105) 面の法線も主延伸方向へ配向する結果といえよ 5 .

Figs. $5 \sim 7$ は, 直交同時二軸延伸（前報1)の試料 B 飞属する） $1.5 \times 1.5$ 倍, $2.5 \times 2.5$ 倍および $3.5 \times$ 3.5 倍各延伸フィルムの (100) 面法線の極点図形を

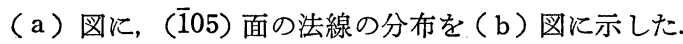
低延伸倍率である $1.5 \times 1.5$ 倍延伸フィルムの（100）
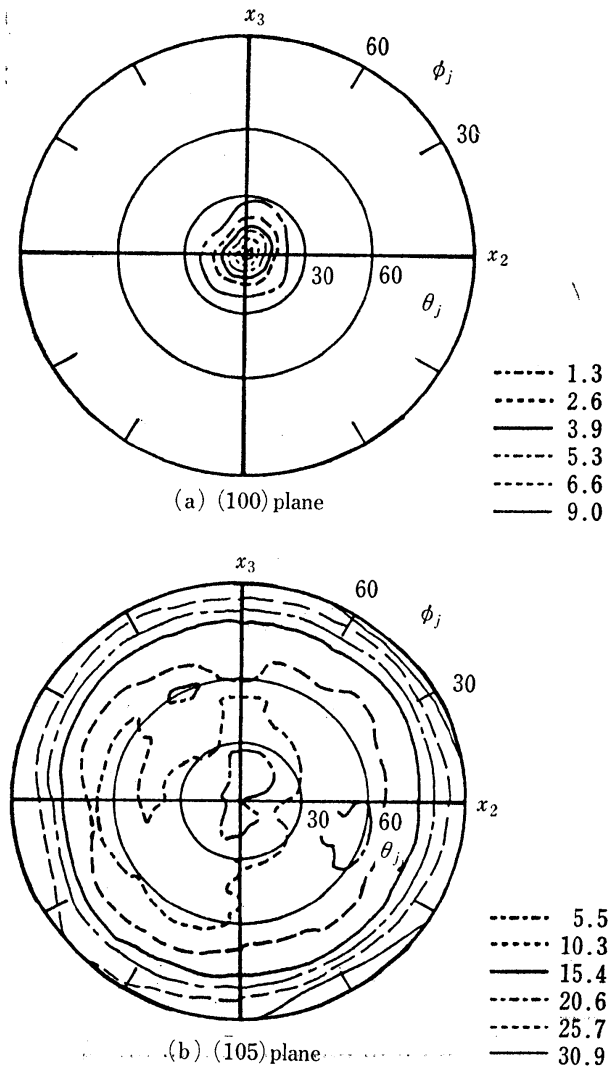

Fig. $6 \mathrm{X}$-ray pole figures of films stretched simultaneous biaxially at $90^{\circ} \mathrm{C}$ and fixed annealed at $200^{\circ} \mathrm{C}$, stretch ratio is 2.5 $\times 2.5$

面法線の配向分布は，一軸拘束一軸延伸 1.5, 2.5 倍 延伸フィルムのものと非常に似かよって, フィルムの 厚さ方向から $\theta_{j}=40^{\circ}$ 注ど傾いた方位角 $\phi_{j}=160^{\circ}$ 特 よび $-40^{\circ}$ 方向に極大を示している.これは，同時二 軸延伸時のフィルム内の延伸効果が不均一になってい る結果である. しかし，分布のすその傾向は丸みをも った配向分布を示しており，全体的には，同時二軸延 伸効果を受けた配向分布の様子になっている.

いっぽう, 同じ Fig. 5 (b) 図では, 極角 $\theta_{j}=60^{\circ}$ 近傍で, 方位角 $\phi_{3}=150^{\circ},-45^{\circ}$ 近傍に極大が認めら れるが、これは（a）四と比較してみると，これらの 位置に極大が現れる点は理解できる ${ }^{11}$. 同時二軸延伸 は面倍率が急激に大きくなるので，各回折面の選択配 向性は顕著になる.Fig. 6 (a)，（b）は，延伸倍率 $2.5 \times 2.5$ 倍延伸フィルムの場合であるが，(a) に示 した（100）面の法線はフィルムの厚さ方向へ強い選 択配向を示し，(b) の (105) 面の法線は, フィルム の厚さ方向から極角 $\theta_{j}$ で $90^{\circ}$ のフィルムの延伸方向 

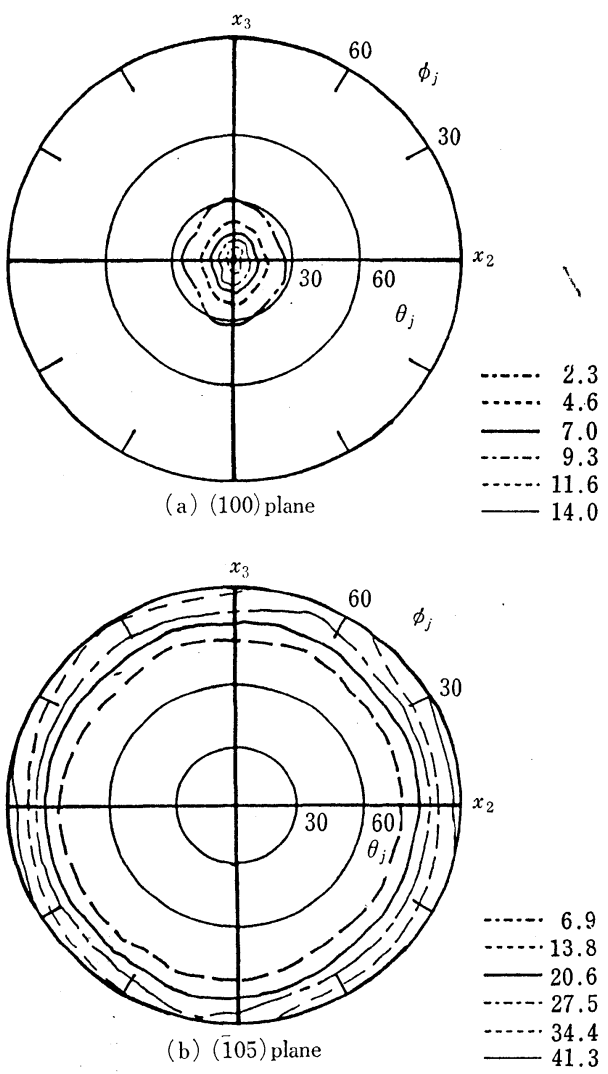

Fig. $7 \mathrm{X}$-ray pole figures of films stretched simultaneous biaxially at $90^{\circ} \mathrm{C}$ and fixed annealed at $200^{\circ} \mathrm{C}$, stretch ratio is 3.5 $\times 3.5$

である $x_{2}-x_{3}$ 面方向に同心円状で強度の極大を示して いる. OB-PET の結晶は，ベンゼン環を含む（100） 面がフィルム面に平行になり，(105) 面の法線が, フ ィルム面内で泳ぼランダム配向になっていることから， 結晶分子鎖軸である $c$ 軸もほぼフィルム面に平行で, かつランダムに配向していると推定できる.この傾向 は, Fig. 7 (a)，（b）に示した延伸倍率 $3.5 \times 3.5$ 倍 延伸フィルムでは，さらに顕著になっている.

次に, 二段二軸延伸系（前報1では，試料 C 亿属す る）フィルムの各延伸倍率試料を Figs. 8〜10 に示し た.

Fig. 8 (a)，（b）は，延伸倍率 $2.0 \times 3.5$ 倍之幅 延伸方向の延伸倍率と主延伸方向の延伸倍率との差が 大きく，一軸拘束延伸に近い主延伸効果を受けている。 （a）図に示した (100) 面の法線は，フィルムの厚さ 方向に強い極大を示している.この等高線分布は $x_{1}$ $x_{2}$ 方向が長い棈円状分布を呈している.これは，主延 伸倍率の効果の表れである. したがって，(b) に示し
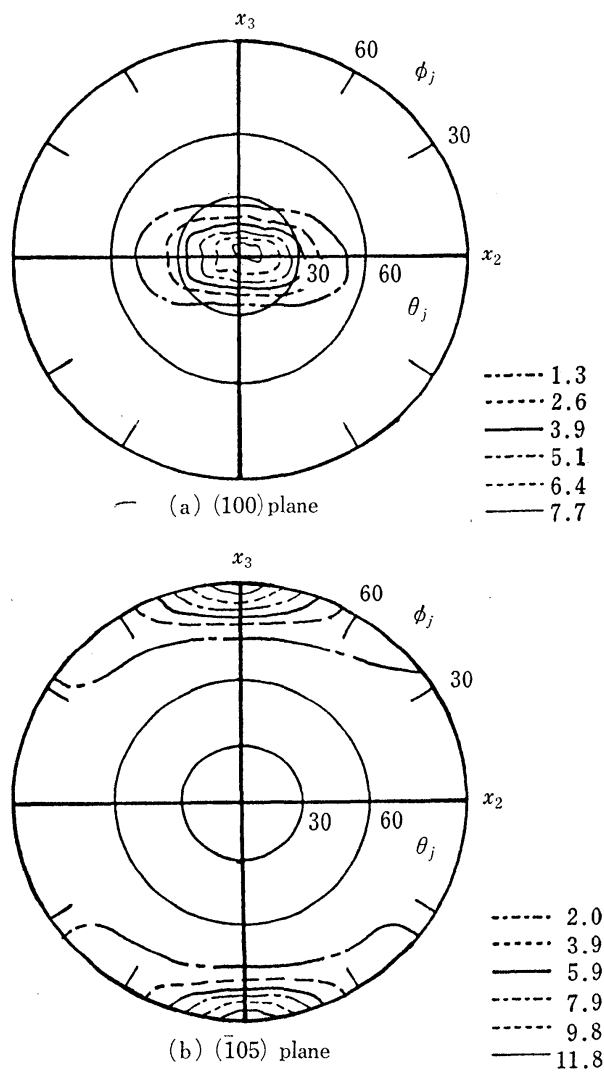

Fig. 8 X-ray pole figures of films stretched two-step biaxially at $90^{\circ} \mathrm{C}$ and fixed annealed at $200^{\circ} \mathrm{C}$, stretch ratio is 3.5 $\times \mathbf{1 . 0}$

た (105) 面の法線は, 主延伸方向である $x_{3}$ 軸方向に 強い極大をもつ配向分布になっている．幅方向の延伸 倍率が増すと, 同時二軸延伸に近い分布を示す. Fig. 9 (a)，（b）は， $2.5 \times 3.5$ 倍延伸フィルムの例を示 した.（a）図の（100）面の法線は非常に強くフィル 么の厚さ方向へ選択配向し，その等高線分布は円に近 い分布している. この傾向は，Fig. 10 (a) 飞示す延 伸倍率 $3.0 \times 3.5$ 倍の試料の (100) 面法線の分布とも よく似かよっている。

さらにこれら Fig.9(b)，10（b)，に示す (105) 面の法線の配向分布の様子が同心円に近く分布 する傾向で，特に，特定の方向への選択配向は消失し， フィルム面に平行でランダムな配向になっている。 こ れは二段二軸延伸は，まず一段目の延伸を同時二軸延 伸するので, この時形成される (100) 面の法線のフィ ルムの厚さ方向への強い選択配向, (105) 面のフィル ム面に平行で，ランダムな配向が一度形成されてのち， 二段目に行ら延伸では，主延伸効果が，次第に薄れる 

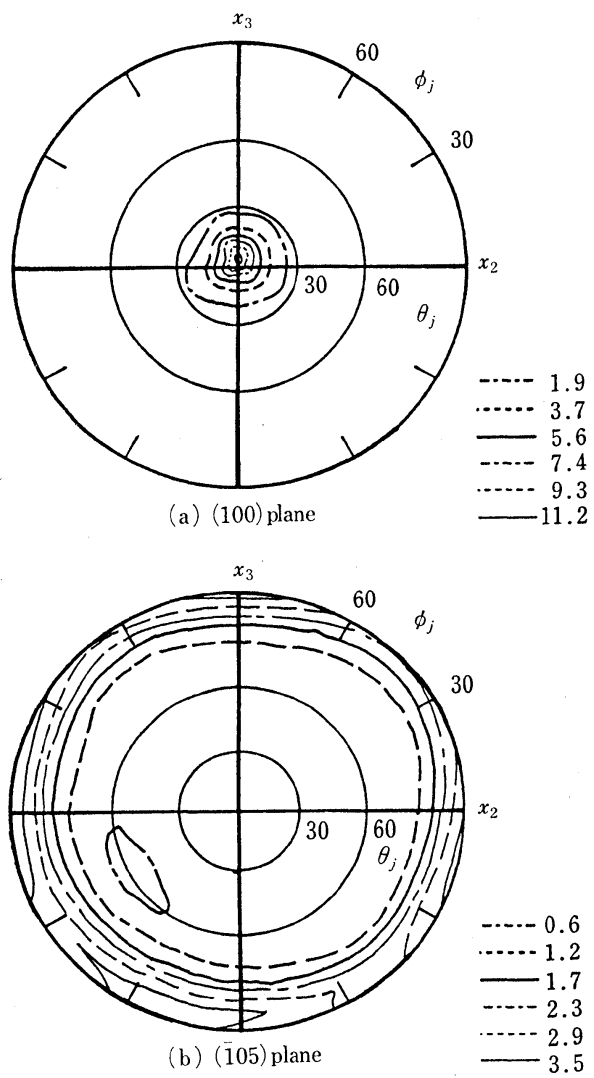

Fig. 9 X-ray pole figures of films stretched two-step biaxially at $90^{\circ} \mathrm{C}$ and fixed annealed at $200^{\circ} \mathrm{C}$, stretch ratio is 3.5 $\times 2.5$

結果と考兄られ.

以上，各延伸方式に基づき延伸したフィルム系の極 点図形の調査を行ったが，これらの結果をもとに，次 報では, 多結晶集合体 ${ }^{6}$,7) による塑性変形時の 微結晶 の配向分布関数の評価を行い, 各 OB-PET フィルム 内の結晶滑り系の発生機構を解析する.

\section{4. 結 論}

OB-PET フィルムの各延伸方式で延伸した系の試 料を, 広角X線回折装置に極点図形内析装置を付設し た測定系で測定し，PET の (100)，(105) 各回折面法 線の配向分布の様子を調查し，次の各結論を得た。

(1) 直交二軸延伸系 PET フィルムでは, ベンゼン 環を含む (100) 面の法線は,フィルムの厚さ方向 へ強い選択配向する. しかし，延伸倍率が低い場 合, フィルムの厚さ方向から, 極角 $\theta$ ～が $30^{\circ} \sim$ $45^{\circ}$ 傾いた方向へ選択配向するが，これはポリエ チレン結晶のロール圧延時に現れる（200）面の
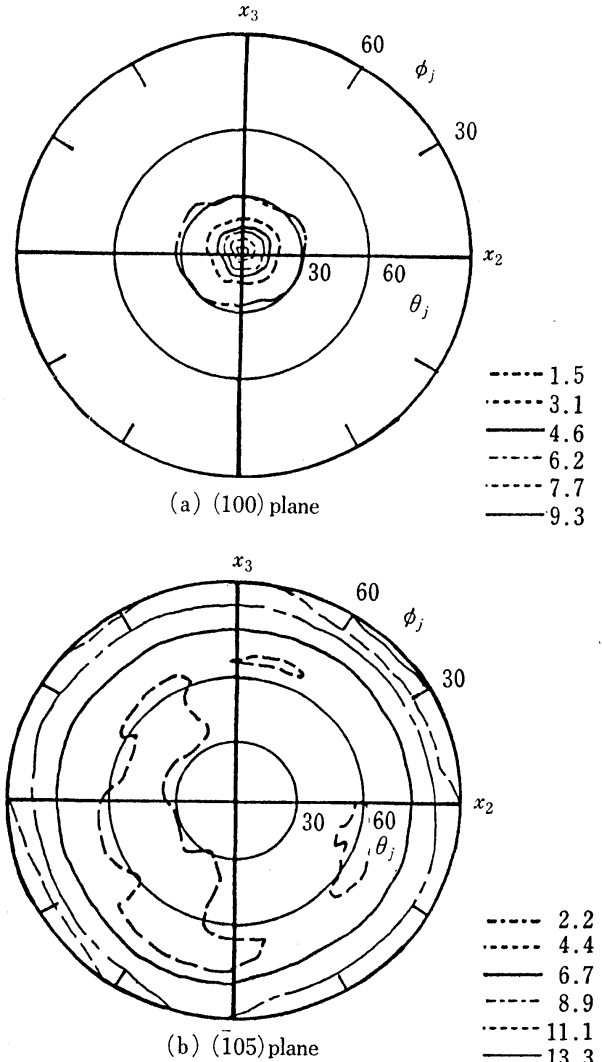

Fig. 10 X-ray pole figures of films stretched two-step biaxially at $90^{\circ} \mathrm{C}$ and fixed annealed at $200^{\circ} \mathrm{C}$, stretch ratio is 3.5 $\times \mathbf{3 . 0}$

選択配向の様子と類似した選択配向である.

(2) 結晶分子鎖軸である $c$ 軸と約 $10^{\circ}$ 傾いた方向 の (105) 面の法線は, 各延伸系ともフィルム面に 平行に配向する傾向にあり，主延伸倍率之副延伸 倍率との差が大きくなる延伸系では，主延伸方向 へ選択配向する.

いっぽう，延伸倍率の差が小さいとき，面内ラ ンダム配向になる. これら両者の面法線の配向挙 動を調査した結果，（100）面のフィルム面に平行 になる強い選択配向に従って，(105）面の配向が 続く関係にあることが明らかになった.

付 記

本研究を行らにあたり, 試料を提供いただいた鐘紡, 高分子事業部下川順造課長に深謝する.

参考文 献

1）図師泰伸，丹羽貴裕，日比貞雄，永田紳一,谷知, 
成形加工， 7 (11)，723 (1995)

2) Cunningham, A., Davies, G. R. and Ward, I. M.: Polymer, 15, 743 (1974)

3) Cakmak, M., Spruiell, J. E., White, J. L. and Lin, J. S.: Polym. Eng. Sci., 27, 893 (1987)

4) Gohil, R. M.: J. Appl. Polym. Sci., 48, 1635, 1649 (1993)

5) Gohil, R. M.: J. Appl. Polym. Sci., 52, 925 (1994)

6) 鳥居隆司, 日比貞雄, 隅田克彦, 牧野博文, 前田 松夫, 中西英二：高分子論文集，45，371（1988）

7) 鳥居隆司, 日比貞雄, 隅田克彦, 栗生好人, 前田 松夫, 中西英二：高分子論文集，45，391 (1988)

8）鈴木浩司, 日比貞雄, 鳥居隆司, 小林雅明, 中西 英二，前田松夫：高分子論文集，44，491（1987）

9）鳥居隆司, 日比貞雄, 児玉栄司, 中西英二, 前田
松夫, 藤本浩一：高分子論文集, 44, 903 (1987)

10）日比貞雄, 鈴木浩司, 平野妙子, 鳥居隆司, 藤田 健一, 中西英二, 前田松夫 : 高分子論文集, 45 , 237 (1988)

11) Hibi, S., Niwa, T., Wang, C., Kyu, T., and Lin, J. S.: Polym. Eng. Sci., 35, 902 (1995)

12) Hibi, S., Niwa, T., Mizukami, J., Wang, C. and Kyu, T.: Polym. Eng. Sci., 35, 911 (1995)

13）丹羽貴裕, 水上 潤, 長谷川智, 杉本雅信, 日比 貞雄 : 高分子論文集, 51, 17 (1994)

14）丹羽貴裕, 長谷川智, 水上 潤, 斉藤秀夫, 日比 貞雄：高分子論文集, 51, 77 (1994)

15) Culity, B. D.: Elements of X-Ray Diffraction, 松 村源太郎訳, X線回折要論, 291 (1961) アグネ

16）文献 15), p. 288 